\title{
CLINICAL LEGAL EDUCATION: A VIRTUAL MODE OF ACCESS TO JUSTICE
}

\author{
Dr. Gigimon V.S. E Ms. Shruti Nandwana ${ }^{1}$
}

\section{Abstract}

Legal education, all over the world uses a mix of practical and theoretical means to train students. For purposes of practical training, specialized legal clinics are established by legal education institutions to train the students to apply the classroom learnt law in live cases. These legal clinics serve dual purposes, first, of training students in the practical aspects of the law and second, providing access to justice to people in areas where it is difficult to get legal help and where reaching institutions of justice delivery is difficult. The pandemic situation prevailing world over now has had deep impacts in imparting legal education. The physical classrooms have turned into virtual classrooms, delivering only theoretical education and leaving doubts in the mind of students due to lack of practical training resulting from non-functioning of legal aid clinics in this situation. In order to ensure access to justice in India during the time of pandemic, the judiciary has taken recourse of virtual courts, whereby the

\footnotetext{
${ }^{1}$ Dr. Gigimon V.S. is Associate Professor of Law, Dharmashastra National Law University, Jabalpur. Their contact details are Contact Number +91- 8123011980, Email ID- profggvs@gmail.com. Ms. Shruti Nandwana, Assistant Professor of Law, Dharmashastra National Law University, Jabalpur. Their contact details are Contact Number +91-7987179434, Email ID- shruti@mpdnlu.ac.in
} 
listing and hearing of cases which require urgent hearing are done online. The same methodology has also been adopted by the National Legal Aid Service Authority by conducting virtual Lok Adalats where cases are entrusted to them ${ }^{2}$. By studying the same mode of virtual courts and virtual Lok Adalats, the present paper aims to devise a working model to ensure that clinical legal education is continued in India during these times of pandemic, and that legal aid clinics work efficiently to ensure that people are not deprived of their right to legal assistance. The working model proposes a collaboration between the legal aid clinics of the universities and colleges and the justice delivery institutions to ensure dual purpose of legal aid clinics is met. The model will also be tested in the institution, and a pan India plan of action for implementing this model would be devised.

\section{Introduction}

Legal education is incomplete without practical training. Clinical legal education is a method of 'learning by doing' where students are trained in the practical skills of how the law works in action. In the words of Prof. N.R. Madhava Menon, the pioneer of legal education in India, clinical legal education is

"A learning environment where students identify, research and apply knowledge in a setting which replicates, at least in part, the world where it is practiced. It almost

\footnotetext{
${ }^{2}$ Lok Adalats are a form of alternative dispute resolution see https://nalsa.gov.in/lok-adalat
} 
inevitably means that the student takes on some aspect of a case and conducts this as it would be conducted in the real world." 3

This clinical legal education serves the dual purpose of imparting practical skills to students and ensures access to justice to the deprived and distressed sections of society. Clinical legal education in India has been made a mandatory part of law course curriculum and most law schools take it up in the form of legal aid clinics/cells which function in their universities/ law colleges. They aim to provide a public service and access to justice to those who are unable to approach the justice delivery institutions in the country. However, the COVID-19 pandemic has created unique challenges to legal education and to access to justice. With universities and colleges being shut down due to the pandemic, teaching has shifted online through virtual means. This has ensured that imparting theoretical knowledge is not hampered, however, it has posed serious obstacles in imparting practical training with most legal aid clinics/cells in universities/colleges being shut down. Similarly, courts of law in response to the pandemic suspended their physical functioning and hence this has caused a hurdle in access to justice to public at large. The Indian judiciary responded quickly and embraced technology by adopting virtual means to hear cases to ensure that the functioning of the courts is not impeded. The Lok Adalats in India which are intended to ensure legal aid to large numbers of people has also adopted virtual means to settle disputes. Hence, there becomes a pressing need that the legal aid clinics/cells

\footnotetext{
${ }^{3}$ N.R. Madhava Menon, Clinical Legal Education, Eastern Book Company, 1998
} 
in India adopt virtual modes of functioning to ensure that the pandemic does not obstruct their functioning

The issue of practical training which is curtailed during this period can be resolved if we try to use technology, that had aided the government and judiciary, to continue to reach the needy. The present paper is looking to propose a working model for ensuring that these legal aid clinics/cells use technology platforms to function during the pandemic and continue even after the situation is overcome. The first part of the paper briefly discusses clinical legal education in India. It then moves on to discuss Lok Adalats and the e-Lok Adalats which were conducted in India during the pandemic and their success. The next part of the paper discusses various successful legal aid initiatives undertaken by students from various law schools prior to and during the pandemic times. Finally we move on to discuss the working model for functioning of legal aid clinics virtually.

\section{Clinical Legal Education in India}

The Indian Constitution, provides that the citizens should be provided social, economic and political justice. ${ }^{4}$ The Indian Constitution also guarantees legal aid to citizens in case of violation of their rights. ${ }^{5}$ Despite strong basis for legal aid in the

\footnotetext{
${ }^{4}$ Preamble to the Constitution of India

${ }^{5}$ Article 39A, Constitution of India
} 
Constitution, the concept of legal aid and clinical legal education emerged relatively late in India. In 1949, the Bombay Legal Education Committee for the first time recommended that practical courses should be made compulsory for those students who wish to enter the legal profession. ${ }^{6}$ This was the starting of CLE in India. Various committees and commissions have been set up in India to ensure that legal aid reached the needy and deprived section of the society.

The Government of India legislated the Legal Service Authority Act,1987 in order to ensure free legal aid to citizens who cannot afford it. The Act has established legal service authorities at three levels - National, State and District level which are responsible for providing free legal aid and ensuring that the needy sections of the society get legal representation. However, it was understood that given the large population of India, the number of people who are eligible for free legal aid is huge and the instrumentalities of the state are not enough to support free legal aid programs for all. Hence, various committees were set up which suggested that including law schools in legal aid programs would serve dual purposes, first to train students and develop their skills, which are necessary for practically implementing what they have learnt in theory in law schools, and second to ensure that access to justice is ensured for all. ${ }^{7}$ The committees also identified seven components of legal aid which include

\footnotetext{
${ }^{6}$ Frank S. Bloch \& Iqbal S. Ishar, Legal Aid, Public Service and Clinical Legal Education: Future Directions from India and the United States, 12 MiCH. J. INT'L L. 92 (1990).

${ }^{7}$ Government Of India, Ministry of Law, Justice And Company Affairs, Department Of Legal Affairs, Report of Expert Committee On Legal Aid : Processual Justice To The People (1973). Government of India, Ministry f Law, Justice and Company Affairs, Department of Legal Affairs, Report on National
} 
legal representation, advice, awareness, paralegal services, public interest litigation, promotion of alternative dispute resolution and legal reforms. All the aforesaid components of legal aid can be achieved by means of legal clinics in law schools except for the first one. ${ }^{8}$

On the basis of reports of various committees, Bar Council of India, which regulates legal education in India, used its authority given to it under the Advocates Act 1961 and issued an order making it compulsory for all law universities and colleges to include four practical papers in their course curriculum. The first practical paper includes moot courts, second relates to drafting, pleading and convincing, third deals with professional ethics and the fourth paper is concerned with training students in legal aid. This resulted in CLE becoming an integral part of law school training where it became mandatory for the final year students to undertake legal aid programs and services in order to get practical training and develop lawyering skills. Universities and colleges across India have adopted diverse means to implement the practical paper on legal aid in their institutes. Some have joined up with Non-Governmental organisations in order to assist them in legal aid and advising them, some of them adopted certain local areas in order to provide legal aid to the residents of those areas, the most common method adopted by the universities and colleges was to set up legal aid cells in order to meet the object of practical training. These legal aid cells serve

Juridicare: Equal Justice - Social Justice (1977). Report of Committee for Implementing Legal Aid Schemes (CILAS) 1981

${ }^{8}$ Since Law students in India are not allowed to practice before the completion of their degree. 
diverse needs of ensuring spreading awareness, imparting legal advice, and ensuring the underserved section of the society is given legal representation. These legal aid cells also establish legal clinics to carry on their activities and tie up with lawyers to act on pro bono basis in order to represent the weaker section of the society.

\section{Lok Adalats and the functioning and success of $e$-Lok Adalat}

The Lok Adalats are set up under the Legal Service Authorities Act, 1987. The Act aims to constitute legal service authorities in order to provide competent and free legal services to the economically deprived and distressed sections of the society and to organise Lok Adalats to ensure that access to justice on equal basis is ensured to all. Lok Adalat is a forum where cases which are pending in the court of law or are at a pre-litigation stage are compromised/settled amicably. Lok Adalats were established in order to ensure speedy disposal of cases where settlement is possible. Cases which are referred to the Lok Adalat are of civil nature, matrimonial cases, Motor Accidents Claims and petty offences. The essence of Lok Adalat proceedings is that the parties should be willing to amicably settle the disputes between them.

The COVID-19 pandemic had resulted in suspension of regular functioning of Lok Adalats in various states. This resulted in serious hardships to persons whose cases were referred to the Lok Adalats. In order to cope up with the pandemic the Legal Service Authorities of various states adopted virtual means to conduct Lok Adalats. Hon'ble Justice N.V. Ramana, Judge, Supreme Court of India and Executive 
Chairperson of the National Legal Services Authority, while talking about e-Lok Adalats said "We [the judiciary] always thought of making use of technological services like video conferences, e-courts, etc. to enable marginalised people to access justice. Now, finally it has been put into action." 9

In order to conduct e-Lok Adalat, states adopted different platforms such as videoconferencing, website or mobile applications developed specifically to conduct e-Lok Adalats to connect the judges, lawyers, authorities and litigants. The first step in each case involved identification of cases which can be settled or decided in Lok Adalats. Post identification, the parties involved were contacted and asked whether they wanted their case to be decided in Lok Adalat. On the basis of this, the number of cases is identified, and necessary benches are constituted to deal with the cases by means of videoconferencing or other digital platforms. The Secretary of District Legal Service Authority has to ensure that the litigants who consent to their matters being taken up for virtual Lok Adalats, fill in a form for referring the dispute to Lok Adalats. Once the benches are constituted, links are created for each case and the information is uploaded on the websites of District Court. WhatsApp groups are created by the District Courts for the parties and advocates to give them information and communicate smoothly regarding the cases. On the date and time designated for the case to be heard, the parties and judge joins the link. The parties are heard, and the

\footnotetext{
${ }^{9}$ Concept of e-Lok Adalat has potential to transform legal landscape: SC judge, September 19, 2020 https://www.thehindu.com/news/national/karnataka/concept-of-e-lok-adalat-has-potential-totransform-legal-landscape-sc-judge/article32650701.ece
} 
matter is decided. The award of the Lok Adalat is uploaded on the district court website which can be accesses by the litigants and lawyers. ${ }^{10}$ E-Lok Adalats have been a huge success in various states and states have settled thousands of cases on a single day in e-Lok Adalats. The following is the data on cases settled in one day in various states by means of e-Lok Adalat: ${ }^{11}$

\begin{tabular}{|c|l|l|}
\hline $\begin{array}{c}\text { Serial } \\
\text { No. }\end{array}$ & State - e-Lok Adalat was held & $\begin{array}{l}\text { Number of } \\
\text { cases settled }\end{array}$ \\
\hline 1. & Delhi & 5838 \\
\hline 2. & Jharkhand & 3,308 \\
\hline 3. & Karnataka & $1,50,000$ \\
\hline 4. & Chhattisgarh & 2270 \\
\hline 5. & Tamil Nadu & 70,000 \\
\hline 6. & Andhra Pradesh & 1,222 \\
\hline 7. & Haryana & 104 \\
\hline 8. & Uttarakhand & 1,787 \\
\hline 9. & Gujarat & 10,954 \\
\hline 10. & Punjab & 19,432 \\
\hline 11. & Rajasthan & 33476 \\
\hline 12. & Jammu and Kashmir & \\
\hline & Total & \\
\hline
\end{tabular}

Student Initiative legal Aid programs - COVID -19

\footnotetext{
10 SOP for conducting India's First State Level E-Lok Adalat or VC Lok Adalat in Chhattisgarh 11 The data has been taken from the website of District Legal Service Authorities of the respective states.
} 
University and college students across India have taken initiatives to assist the needy and deprived sections of the society to make them aware of their rights and to ensure that justice is done. In a few such cases, students from various National Law Universities from different parts of India have come together to assist people to get their rights enforced. A few of such initiatives for legal aid by students at a pan India level are:

- Mazdoor Mitra: COVID - 19 forced nations to call for a nation-wide lockdown in the initial stages as a measure to control the virus from spreading. During these difficult times of lockdown, the most severely hit were the daily wage earners and migrant labourers who left their homes and travelled kilometres to find employment. They were left stranded and were unable to contact their state governments to transport them back to their respective states. The students from National Law Institute University, Bhopal joined hands to assist the migrant labours to procure food, arrange night shelters and provided them with e-passes and means of transport to return home. It is an entirely studentled program. Since all educational institutes were also closed during the lockdown period, the students communicated with each other and kept in constant touch through videoconferencing and Whatsapp. They coordinated with various state authorities and NGOs to provide assistance to migrant labourers. The Mazdoormitra website was set up within 24 hours which had contact details of various COVID-19 helpline numbers for states as well as 
labour welfare agencies. The students were available 24/7 through their website and through the contact details furnished on the Mazdoormitra website. Within a month they had solved more than 200 inquiries from migrant labourers from across India, and, were able to connect people during this emergency situation. ${ }^{12}$

- Initiative by students from Gandhinagar National Law University, Gandhinagar: Students and alumni of Gandhinagar National Law University, Gandhinagar (GNLU) came together during the nation-wide lockdown enforced due to COVID -19 to assist the migrant workers to return home. They worked with Zenith Legal Aid Clinic in Madhya Pradesh in order to provide aid to migrant workers with respect to food, shelter and conveyance in order to travel back to their hometown. The team also worked in collaboration with governmental and non-governmental agencies to assist the migrant workers. They provided information to migrant workers regarding trains scheduled for them to travel back home, assisted the labourers to register themselves for trains scheduled for them, assisted the labourer to reach home from the railway station, and tracked the location of migrant labourers on their way back to their homes. They also assisted the governmental authorities and NGOs to connect to labours to provide them with food and shelter facilities. In their first phase

\footnotetext{
${ }^{12}$ Student-led NLIU project assist over 200 migrant labourers with practical advice, help on dealing with lockdown, Wednesday, 20 May 2020 https://www.legallyindia.com/lawschools/student-led-nliuproject-assist-over-200-migrant-labourers-with-practical-advice-help-on-dealing-with-lockdown20200520-11429
} 
i.e. from May 14, 2020 to May 21, 2020 they assisted a total of 6000 workers from Madhya Pradesh who were stranded in Maharashtra. The team has also assisted workers who were being abused by their employers and being forced to work extra hours when they wanted to leave for their hometowns. The team contacted the officials and administration in the area and the workers were given police protection and sent back home. ${ }^{13}$

\section{Technology Assisted Legal Aid Programme}

The initiative by the students of Dharmashastra National Law University, Jabalpur, (DNLU, Jabalpur) the instances stated above in the form of Mazdoormitra, initiative by students from Gujarat National Law University, Gandhinagar as well as the huge success of the e-Lok Adalats in various states forms the basis of our current model for setting up online legal aid clinics connecting law schools pan India.

The present paper proposes a model for setting up collaborative legal aid clinic among law schools pan India which would help to ensure dual purpose of legal aid clinics. The project would be implemented in phases where at the first phase it would be initiated in our University, i.e. DNLU, Jabalpur and would then be based on collaboration of 22 National Law Universities (NLUs) established in different parts of

\footnotetext{
${ }^{13}$ Success stories of assisting migrant Labour, GNLU Centre for Law and Society, 2020 http://www.documentcloud.org/documents/6922849-GNLU-Centre-for-Law-and-Society-GCLSsuccess.html
} 
the country. Post this phase, such NLUs would then collaborate with the law schools in their region to connect the legal aid clinics pan India.

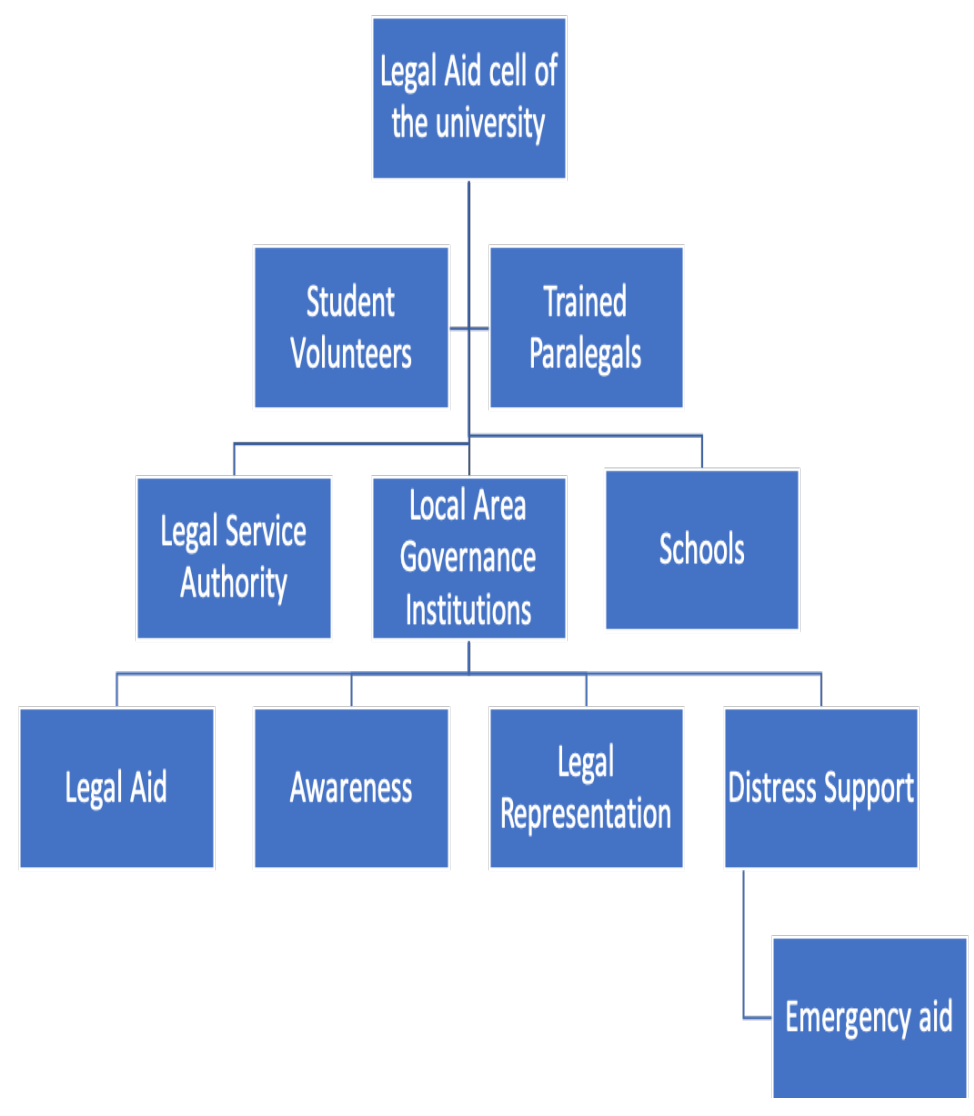

Figure 1 - Parties involved in the functioning of online legal aid clinic

Parties involved:

- Legal Aid cell of the University: The Legal Aid Cell of the University would act as a nodal centre through which all the legal aid activities would be carried out.

- Legal Service Authority: The Legal Service Authority would be contacted to provide requisite support for providing assistance in connecting people virtually. 
- Student Volunteers : Student volunteers would be responsible for running the legal aid clinic for purposes of providing advice; assisting pro bono lawyers to draft the petitions; maintaining the website and web portal for receiving complaints and requests for legal advice; and undertaking all activities at the University Level to run the legal clinics.

- Trained Paralegals - they would undertake advisory work, running of kiosks and assist the students where they need additional support.

- Local area governance institutions: such as gram panchayats and gram nayalaya to help people in distress connect with the legal clinics virtually

- Schools: Legal awareness camps would be set up in schools so as to make students aware of their rights and duties

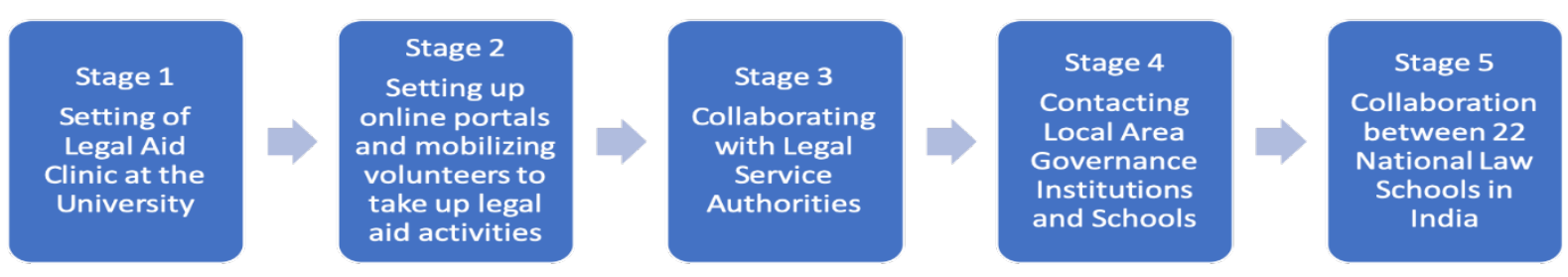

Figure 2: Stages of implementation of the model 


\section{STAGE I}

DNLU, has an active legal aid cell which provides legal aid and advice to citizens in need. The students have been visiting villages to understand the legal issues which people face and to provide advice. Hence, this legal aid cell would act as the nodal centre for implementing the project and establishing legal clinics in their University. As per the legal education regulations of Bar Council of India (BCI) rules, there should be a faculty member who would head the legal aid program in the University, and hence an experienced professor would be designated as the head of the cell who would be responsible for ensuring that the legal clinic functions in a proper manner. BCI mandates training students in legal aid as a compulsory subject for law students, and hence, each year there would be about 100 final year students who would have to take clinical legal education as a mandatory subject and they would be the volunteers in the legal clinics. Apart from the student volunteers, alumni of the University, on a pro bono basis, will be the advisors and lawyers for representing the clients based on advice given to them in the clinics. The volunteers can assist the lawyers in preparing case briefs and representations in cases assigned to them. The legal aid clinic would also recruit certain paralegals to assist them in the activities of the clinic.

\section{STAGE II}

The legal aid clinic would adopt a village nearby to start implementing the project. A website would be created which would give details of the clinics. Helpline numbers 


\section{Practice Report}

would be circulated by way of information pamphlets in areas where the legal aid clinic aims are to start implementing the project so as to make the people aware of the existence of centres where people can access legal help. Apart from the website and helpline numbers, the clinic would have a kiosk which will function once a week in each area where legal aid is to be provided. The kiosk would be managed by trained paralegals and student volunteers working with the clinic so as to ensure that those who are unaware of technology and cannot access websites or helpline numbers are helped at regular intervals. The helpline numbers would also increase take up of those in emergency situations such as domestic abuse where the complainant seeks urgent help. The National Legal Service Authority is entrusted with the task of promotion of clinical legal education and the provision of guidance and supervision for the establishment and working of legal aid clinics in universities and law colleges. Hence, the legal aid clinic at DNLU, Jabalpur can connect with the State Legal Service Authority in order to make the legal aid clinics function virtually. The virtual facilities available with the State Legal Service Authority can be used to provide legal aid to those in distress.

To provide legal aid, the cell at DNLU would establish a portal on its website where the people who require assistance call fill in the requisite details with respect to their case and such details necessary for the students to assist and provide counselling to these persons. The student volunteers would be divided into groups which would specialise in one particular law. The matters as received on the portal would then be 
segregated and assigned to the respective groups. These groups would understand the matter, take assistance from the panel of pro-bono lawyers and ensure that they are well versed with the case at hand. They would then contact their client either through telephonic calls or through videoconferencing in cases where it is necessary. To this end the legal service authorities at the state, district and village level can provide support by creating a setup where such persons who do not have means to connect through video conferencing can come and use the facility to have meetings with the volunteers at the legal aid clinics. These volunteers after meeting with the clients with respect to their cases, will be assigned lawyers who agree to work on probono basis and represent these cases in the court of law. Here the task of the volunteer would be to assist the lawyer in drafting the case and act as an intermediary between the lawyer and the person represented to ensure that there is complete exchange of information. WhatsApp groups can also be created by students so that they connect large number of people together and it is easier to communicate.

\section{STAGE III}

After the initial stage of implementation and working, these legal aid clinics would then contact the district or taluka legal service authorities in their states to refer cases which are fit for settlement through Lok Adalats and ensure that the decisions of the Lok Adalats are implemented. Coordination and collaboration with the Legal Service Authorities would also help these clinics to refer cases which include more complex 
issues to be dealt by panel of lawyers and mediators, empanelled with the Legal Service Authorities and they can help people who require legal aid by representing them.

\section{STAGE IV}

At the next stage, the legal aid clinic would contact the Gram Panchayats (Village Council) and Gram Nayalays (Village Courts) in each village where the legal aid clinic aims to provide legal aid. Gram Panchayats and Gram Nayalays can through their administration provide ways to connect the people to the legal aid clinics via online modes and hence ensure that the people in need are connected to the legal aid clinics in their respective areas. Further, collaborating with gram panchayats can help in spreading awareness among the villagers regarding legal rights and duties, and various welfare schemes which are available and implemented by the government for them. A major challenge in the rural areas in India is that the rural population is unaware of their legal rights and welfare schemes conducted for their benefit. Hence more than providing legal aid, legal awareness among rural people is an important aspect which needs to be taken care of. The student volunteers and the paralegals can take up these activities by contacting the gram panchayats and organising screening of documentaries on legal rights or organising videoconferencing of the legal aid clinic with the villagers to solve their queries and to give them information about laws. Similarly, the legal aid clinics can also organise online legal awareness camps in 
schools by means of videoconferencing to spread awareness among students about their legal rights.

\section{STAGE $V$}

Once the project is successful at DNLU, Jabalpur it can then be adopted by the 22 National Law Universities (NLU) established in each state in India. The NLUs are connected with each other through a consortium which is called Common Law Admission Test (CLAT) Consortium and is responsible for admissions into the NLUS. The CLAT Consortium can act as the central body to regulate the collaborated legal aid activities in the NLUs. Most of these NLUs have active legal aid cells which can act as nodal centres for the implementation of the project in each university. A common portal for all the NLUs can be created where aggrieved persons can submit their legal disputes. The NLUs can within themselves specialise in certain subjects and the cases received on the portal can then be divided among the clinics based on the specialisation. The student volunteers in these clinics can take up the matters at a pan India level using virtual means to connect. This method can also be used to spread awareness among people of their rights and the laws in general. Each legal aid clinic can take up certain areas of laws and impart awareness through videos and online means. The legal aid clinics in each state would be entrusted with the task to ensure that such videos reach the local level and persons are made aware of the same. The 
legal aid clinics can also take up online sessions for students in collaboration with schools to spread awareness among the children of their legal rights and duties.

\section{Conclusion}

Practical learning adds more skills of advocacy for the young, budding lawyers, and will also help them to understand the needs of society at large. Acquiring such knowledge and understating of the socio-economic needs of disadvantaged people, will help the students to learn the implementation process of a legislation and lacunas in it. This will also help the students to be active in public policy formation and implementation. This experiment will be a functional experience for not only the students but for the teachers too. The use of technology in the justice delivery system has already proved successful in the court system in India and is functioning effectively. This led to the idea of the use of technology in legal aid model. The huge success of e-Lok Adalats and that of the student initiatives during times of COVID-19 pandemic in providing legal aid has proved that providing legal aid through online means is possible and very well received by people who do not have much knowledge about it as well. By providing mechanisms for legal aid clinics to function online, the dual purpose of legal aid clinics i.e. to impart practical training and to ensure access to justice can be achieved. Once this model starts functioning, it will ensure that legal aid is always made available to the needy persons and that the collaboration between various NLUs ensures that legal aid achieves its real purpose of providing social 
justice. This will allow us to reach the length and breadth of this vast country where access is difficult, but justice needs to be provided. It is the mandate of the State to provide Justice, to all and it's a basic human right.

\section{References}

Concept of e-Lok Adalat has potential to transform legal landscape: SC judge, September 19, 2020 https://www.thehindu.com/news/national/karnataka/concept-ofe-lok-adalat-has-potential-to-transform-legal-landscape-sc-judge/article32650701.ece Frank S. Bloch \& Iqbal S. Ishar, Legal Aid, Public Service and Clinical Legal Education: Future Directions from India and the United States, 12 MICH. J. INT'L L. 92 (1990).

Government Of India, Ministry of Law, Justice And Company Affairs, Department Of Legal Affairs, Report of Expert Committee On Legal Aid : Processual Justice To The People (1973). Government of India, Ministry f Law, Justice and Company Affairs, Department of Legal Affairs, Report on National Juridicare: Equal Justice - Social Justice (1977). Report of Committee for Implementing Legal Aid Schemes (CILAS) (1981)

N.R. Madhava Menon, Clinical Legal Education, Eastern Book Company, (1998)

Student-led NLIU project assist over 200 migrant labourers with practical advice, help on dealing with lockdown, Wednesday, 20 May 2020 https://www.legallyindia.com/lawschools/student-led-nliu-project-assist-over-200migrant-labourers-with-practical-advice-help-on-dealing-with-lockdown-2020052011429

Success stories of assisting migrant Labour, GNLU Centre for Law and Society, 2020 http://www.documentcloud.org/documents/6922849-GNLU-Centre-for-Law-andSociety-GCLS-success.html 